\title{
LIFE OF LINNAEUS,
}

THE YOUNG, IANIST.


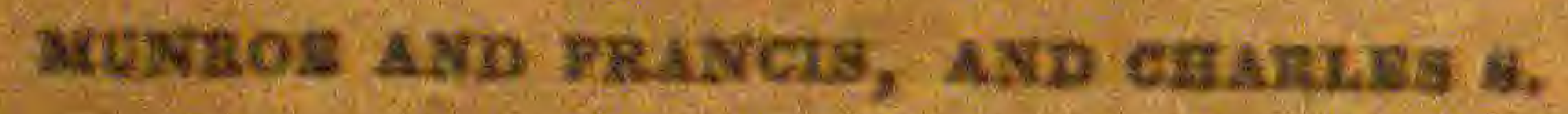
Fravess, Naw-KOnk. 


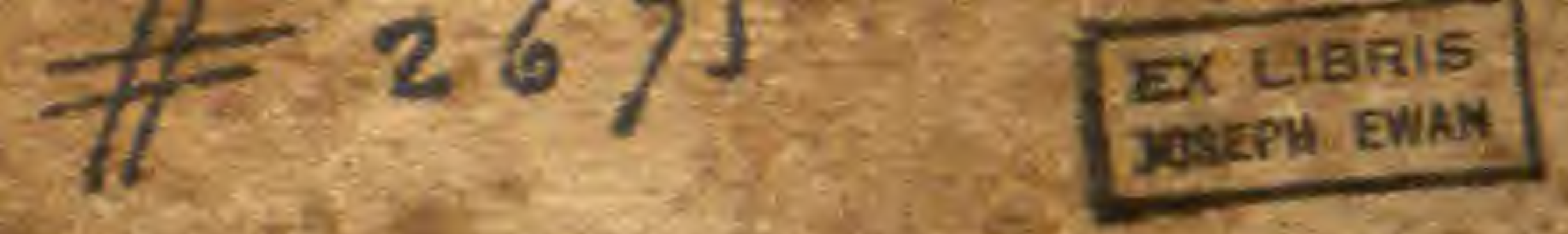

\section{...6. \\ Westminster Church}

\section{SUNDAY SCHOOL LIBRARY.}

\section{REGULATIONS,}

1. No book shall be issued from this Library for a longer period than two weeks.

2. One volume, only, shall be taken from the Library at a time.

3. The books shall be given to those only who attend as scholars.

4. Particular attention must be paid to keeping the books free from injury of any (2) kind,

5. It any book be lost, or materially injured, it must be replaced, or the current price paid for it.

6. The books will be distributed to the - different classes in numerical order, between the hours of 9 and 10) on Sunday morning, by the Director and Directress of the month, they hasing previously received a list of numbers, from each teacher.

N. B. Parents are requested to caution their children to adhere strictly to these regulations.

* * Teachers will keep a eorrect account (2) of books delivered to their class, and report all delinquents. 





\section{YOUNG BOTANIST :}

or,

\section{A SKETCH}

of

\section{THELIFE OF LINNAUS.}

DESTGNED FOR YOUNG PERSONS.

"..... Quel lieu desert n'est plein de sa memoire?

If fit de chaque plante un monument de gloire."

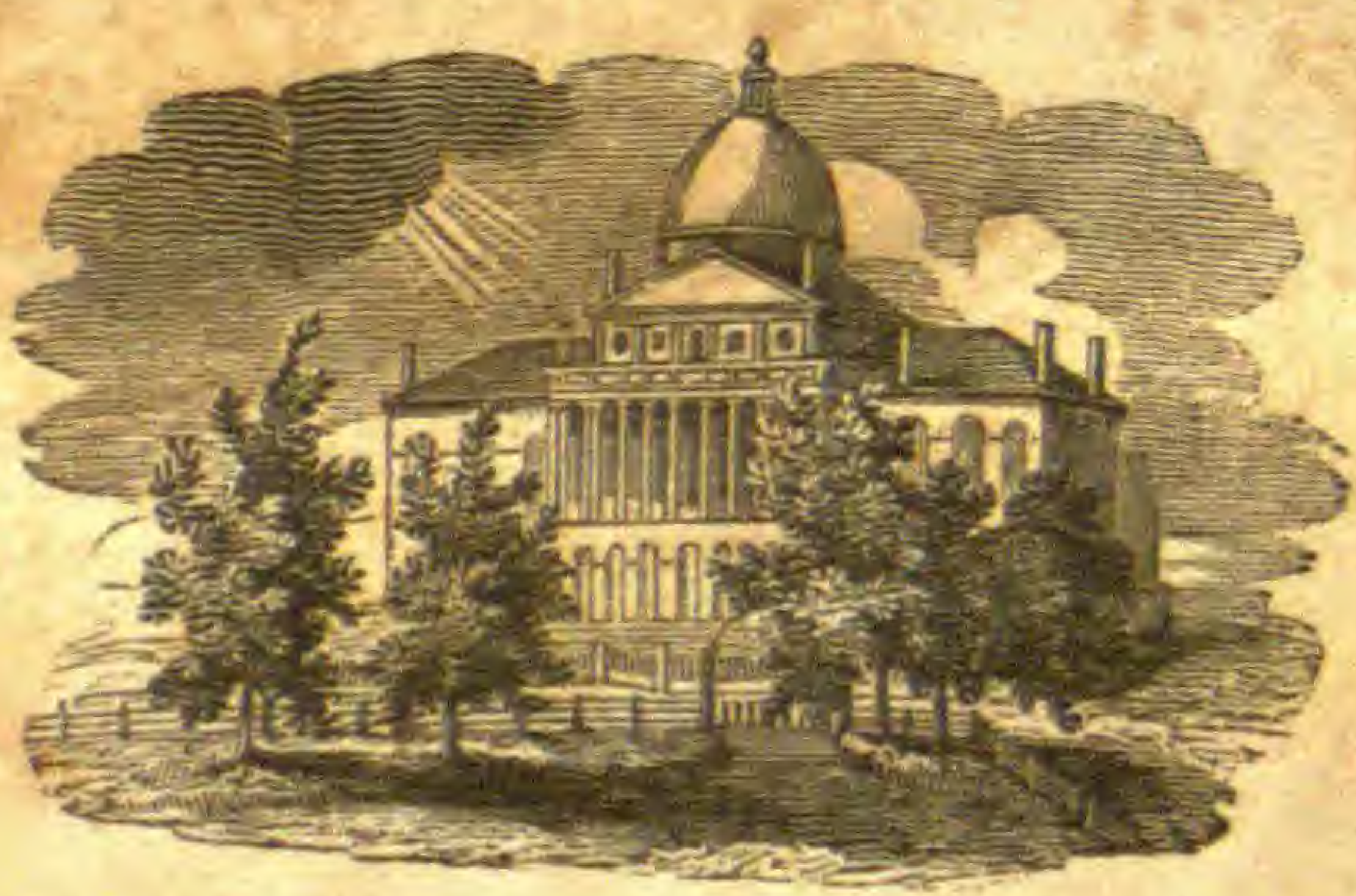

BOSTON :

MUNROE AND FRANCIS, AND CHARLES 8. FRANCIS, NEW-Y ORK. 



\section{PREF ACE.}

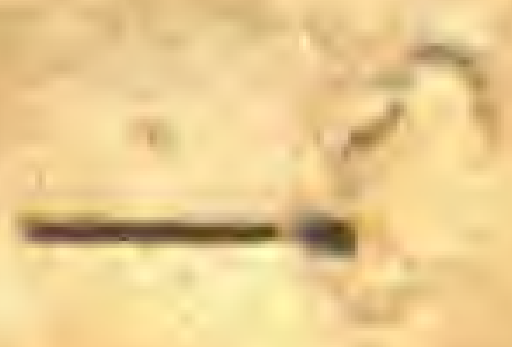

IN the present day, when botany may be reckoned among fashionable studies, it is singular that the life of the great botanist, Linnæus should be so little known.

There are few, we believe, who are acquainted with the uncommon events that marked his course, and the many difficulties he had to contend with; or who have any idea of the persevering industry with which he pursued his object, until at last every obstacle gave way, and success and prosperity crowned his labours.

The following particulars are drawn chiefly from the tour of Linnæus in Lapland, written by himself, and translated into English by Sir J. Smith ; and from Dr. Trapp's translation of the life of Linnæus. The voluminous 
size of this last work, arising from the minuteness of its details, the diffuse style in which it is written, and the quantity of extraneous matter bound up with it, places it beyond the reach of many who would gladly read the simple history of Linnæus.

We have endeavoured to furnish this in a form which, we flatter ourselves, is adapted for the library of the young botanical student.

\section{January, 1829.}




\section{LIFE OF LINN EUS.}

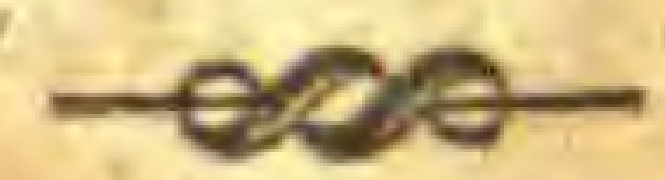

"SEE, Ellen," said Henry Vernon to his sister, as he entered the library, one fine summer morning, and found her engaged in examining the flowers she had collected in a walk the evening before : "see, Ellen," said her brother, "although I laugh at you for your love of botany, I have brought you a flower to pull to pieces ; and I assure you I have taken some pains to procure it for you, as you will believe, when I tell you that it grew on the summit of St. Vincent's rocks. 
"Oh! thank you, Henry: it is quite a new flower to me; and what a long walk you have had for it. How early you must have risen; for it is not yet eight o'clock. What could have led you to Hartwell at that time in the morning?"

"To tell you the truth, Ellen, it was this identical flower that led me there; though you will ridicule the idea, that any poor blossom should have such a magnetic influence on me. I will tell you how it was. About ten days ago, when my cousin George was here, you know we were out in search of butterflies for his cabinet. In the course of our ramble we climbed Hartwell cliff, to see what we could find there; and while he was busy watching some insect, I espied this plant; and it occurred to me, that, as it grew on a spot which it was impossible for you to explore, it was very probable that you had never 
seen the flower. It was, however, only in bud then ; and I knew it was of no use to bring it in that state. And now, how do you think I found out the right time to gather it, at last? You know, Hartwell is not so easily climbed as to make an every-day business of it."

"Indeed, Henry," said Ellen, "I can only suppose that you made a very fortunate guess about the time in which it might be fully in bloom."

"No, no, you will never find out how I managed it. Look ! (holding out a little pocket-telescope) this was the messenger that brought me news from my lady Flora on the cliff. Every two or three days I went to the foot of Hartwell, and looked at the plant through my glass; for it was so situated, that I could clearly distinguish it by means of the telescope. During our walk to Leigh Wood, last evening, while you and mother and father rested 
yourselves, I took another peep at Madam Flora, and saw, to my great satisfaction, that her ladyship was dressed out in blossoms ; and this morning I was off on my travels, before you were stirring, early riser as you boast yourself to be."

"Well, Henry," said Ellen, "it is quite an adrenture; and I am sure you have made up, by your kind attention, for all the ridicule you have bestowed on my favourite pursuit."

"Good morning, Henry," said Mr Vernon, who now came forward from a recess formed by a bay-window, in which he had been writing, unperceived by his son, "Good morning: I am glad you have been out so early, in this fine, pure air ; and I am still more gratified that you have devoted your time and your labour to contribute to your sister's pleasure." 
"And it is quite a new flower to me, father," said Ellen, "and I dare say it is to mother too; so I shall not examine it till she comes, that we may enjoy it together."

"You are right," said her father; "and now, as it is not quite breakfasttime, suppose we take a turn round the flower-garden, and see the beautiful productions of other climates; which "Nice art, in beds and curious knots,"

has placed, as Milton says."

Ellen, now in her sixteenth year, with a mind highly cultivated by the constant assiduity of her parents, and particularly of her amiable and intelligent mother, was keenly alive to all the beauties of nature. Her brother, a year younger, was not devoid of sensibility on the subject; but he was of a less contemplative cast of character than Ellen; and besides, he was still a true school-boy, and rather prone to 
think lightly of women's pursuits, as unsuited to the dignity of the manly character. As they entered the garden, the fragrance of a thousand blossoms regaled their senses, and the young people exclaimed together, "How delightful!" "And now, father," said Henry," after all, do you not like these sweet roses and jessamines better than all Ellen's wild plants?"

"Really, Henry, at this moment I think, with you, that nothing can be more delightful, or more like 'flowers worthy of Paradise,' than these roses and jessamines, and the other fragrant blossoms by which we are surrounded. You know, too, that I am passionately fond of a garden. Do you remember the beginning of lord Bacon's chapter on gardens, which I showed to you the other day ?"

"Oh! yes, father, I remember, he writes as if he had so completely enjoy- 
ed the thing himself, that he communicates some of his warm feeling on the subject to his reader."

"That is, in truth, the case," said Mr Vernon. "Ellen, my love, you are acquainted with lord Bacon's name and character, though, I believe, I have not introduced you to a knowledge of his Essays; which, however, I hope at some future time to read with you. With regard to the passage we have just alluded to, I am sure, fond as you are of your wild plants, as Henry calls them, you will be charmed with his praise of gardens. He says : 'A garden is the purest of human pleasures : it is the greatest refreshment to the spirits of man ; without which, buildings and palaces are but gross handyworks : and a man shall ever see, that, when ages grow to civility and elegancy, men come to build stately, sooner than to garden finely; as if gardening 
were the greater perfection.' But, though I thus commend gardens, Henry, observe, that I do not mean to undervalue the many curious and beautiful plants which spring up uncultured in our fields and woods. Neither do I like to hear you speak so slightingly of your sister's favourite study. My professional avocations have left me little leisure for the pursuit of many branches of knowledge, which were, at one time of my life, very interesting to me. This has been the case with botany. You have been accustomed to see your mamma and sister engaged in it with much more ardour than any other members of the family ; and therefore, I believe, you fancy that it is not a subject suited to what you consider the stronger powers of your sex. Tell me, is not this your idea?"

"Y Yes, papa, that is exactly what I have thought about it ; because, 
though I knew you had some knowledge of botany, I never saw either you or my brother Charles appear to take that continual interest in it which mamma and Ellen do."

"This is very true, Henry ; nevertheless, you will be surprised to hear, that the study of botany must form a part of your own education, as a physician. Your brother's attainments, in most respects, may be considered as precisely what you should aim at; but there are some points in which a difference will be necessary, since your professions are so dissimilar. It would have been no peculiar advantage to Charles, as a special pleader, to have acquired the particular branch of knowledge in question, though it would have added to his stores of intellectual enjoyment. But, in the profession for which you are intended, it is indispen- 
sable ; as you will find, when you arrive in Edinburgh to pursue your studies there, if not before. Many of the medical students, I believe, go with prejudices like yours, or such as are equally unreasonable, and consider this study the most uninteresting they are called to engage in. Now let us see whether we cannot make your path pleasanter, by awakening in your mind an interest in the pursuit, before you are compelled to enter on it. I would advise you to take a few lessons of Ellen, whenever you are at home in the season of flowers. I fear I shall be too much engaged, during the short time that remains of your present holidays, to pay much attention to you on this or any other subject; but I will undertake to do my part, by relating to you, in letters, some of the most striking passages in the life of Linnæus, the great naturalist, whose system of 
botany has now completely supplanted that which formerly prevailed. He was so interesting and uncommon a character, that I do not despair of communicating to you a portion of his enthusiasm, and throwing a charm around the study, by the detail of his adventures and difficulties, and the final success of his persevering exertions."

Henry accepted his father's offer with pleasure ; enlisted himself, as he said, under Ellen's banners ; and sticking a daisy, he had gathered on the lawn, in his hat, he declared that he had assumed the order of Flora. The whole party entered the breakfast-parlour in high spirits. They found Mrs. Vernon seated at the table; and after exchanging the morning gratulations with her, they told her of the plan which had just been resolved on, and which, as might be expected, received her approbation. 
The breakfast-hour was usually a cheerful and pleasant season at Mr. Vernon's. It was only for a few days more, that Henry was to enjoy, for the present, this and other social hours with his family. The holidays passed quickly away, and the affectionate and kinehearted boy parted from his family with sorrow. The following week, he received with great delight the fint of the promised letters from Mr. Vernon. 


\section{LETTER I.}

\section{My dear Boy,}

I sEIze the first leisure halfhour that occurs, to fulfil my promise of giving you some details of the life of the great Swedish naturalist. As your sister will write of home-affairs, I have nothing to do but to set out with you at once to the shores of the Baltic. In the tongue of land which so nearly approaches the territory of Denmark, you will find the province of Smaland. In a small village in this province, Linnæus was born. His father, a clergyman of the Swedish church, in very limited circumstances, was descended from a 
race of peasants. Some of these had, however, quitted their rustic calling, to pursue the study of literature; and changing their name with their occupation, they had, in the seventeenth century, assumed that of Lindelius, or Tiliander, (linden-tree-man,) from a large linden or lime-tree, which grew in the vicinity of their dwelling. The practice of adopting a new name from some external circumstance, is not unusual in Sweden. The father of the naturalist followed the example his kindred had set him. The family lindentree was still standing; and he borrowed from it the name of Linnæus, which the genius of his son has since rendered so celebrated in every quarter of the globe.

Charles Linnæus, the hero of our narrative, was born on the 3d of May, in 1707 , at the village of Rashult, where his father dwelt, dividing his 
time between the duties of his pastoral office and the cultivation of his garden. The elder Linnæus was a great lover of gardening; and a very limited income made the productiveness of his parterres, at the same time, an affair of pecuniary interest; the sale of his flower-roots making an important addition to his means of support. In this simple scene of rural industry, the first year of the life of Linnæus was passed. Flowers were his first playthings; and it is said that the infant naturalist manifested unusual delight while gazing on their bright colours, and inhaling their fragrance. To use the words of a French poet :

'Le Zéphyre agitant ses ailes odorantes

Porta vers son berceau les doux parfums des plantes;

Déja ses yeux fixaient leurs formes, leurs couleurs, Et ses mains pour hochet demandèrent des fleurs.?

Some persons have imagined, that to this circumstance in his early life may 
be traced that passion for flowers which his later years exhibited. Before he had reached his second year, the circumstances of his father were somewhat improved by the gift of a more lucrative benefice. On removing to the new living, the good man was delighted to find an extensive garden attached to the ministerial residence. the addition to his income Although Although
was not such as to render him a rich man, he was no longer compelled to cultivate his ground as a means of contributing towards the support of his family. He now luxuriated in the indulgence of his taste as a florist, and in a few years his garden became one of the finest in the district. He cultivated there upwards of four hundred species of flowers, and many of these were rare exotics. In these simple pleasures the Swedish pastor sought recreation from the duties of his sacred office. As soon as his little 
boy was old enough to play in the garden, he became his constant companion when there. Whenever his father was employed in rooting up his curious bulbs, or transplanting a valuable root, or supporting a stem of a favourite flower, Charles was to be seen gambolling by his side, ready to aid him in his labours by watering the beds, or doing any thing which the careful florist would entrust to his youthful assistant.

To encourage in him a love of these pursuits, when he had attained his eighth year a spot of ground was set apart, and distinguished by the name of "Charles's Garden." The little naturalist was greatly delighted with this acquisition. He resolved to bring into his Lilliputian territory every variety of flower within his reach, and began to explore the neighbouring fields and woods in search of supplies. Ma- 
ny a prize did he find in these sylvan retreats, and often did he return home laden with treasures, and as happy in the discoveries he had made, as though they had been of far greater value. Many of the wild plants, thus introduced to a richly-cultivated soil, spread and multiplied, and added so much to the labour of the gardener, that his father was obliged, at length, to set some bounds to the practice. But, not content with the stores of the vegetable kingdom, the adventurous youth began to seize on the insect tribe ; and having succeeded in taking prisoners some wasps and wild bees, he brought them home to colonize his garden. The new inmates found themselves in a land flowing with milk and honey, and soon made desperate attacks on the hives of the domesticated bees; and, like the Goths and Vandals inva- 
ding the nations of civilized Europe, of which you were reading last winter, threatened to destroy the inhabitants, and lay waste the possessions of these little monarchies. Poor Charles was severely reprimanded for this inconsiderate deed, and bound over to abstain from such proceedings in future. Meantime, he continued to roam through field and wood; and while he added to his little fund of knowledge, by the observations he made on the flowers and insects collected in his rambles, he deepened in his heart that enthusiastic love of nature, which was his marked characteristic through life.

I flatter myself, Henry, that you begin to feel some interest in Linnæus ; and that you even wish you could climb Hartwell cliff or explore Deerhurst wood with the young adventurer.

Good bye, my dear boy : I am lim- 
ited for time ; besides, I cannot proceed further, until you tell me whether you wish to hear more of my hero. Your affectionate Father,

C. V. 


\section{5}

\section{LETTER II.}

Mr Dear Henry,

Since yon tell me that you have added Linnæus to your list of friends, and are resolved that he shall be the companion of your future rambles, I feel happy to have it in my power to promote the growth of your acquaintance, without further delay. We left him busy in cultivating his little garden, and roaming in search of flowers and insects. He could not have found a mode of life better suited to his age and to his active propensities, or better calculated to gratify the inclinations of his enquiring mind. His 
father promoted these pursuits, as tending to keep the boy in health by the exercise they induced him to take. He considered them too as safe and innocent diversions, which would not interfere with the acquisition of knowledge on other subjects more important to him in the profession for which he was intended. The parents of Linnæus had determined that their son should be a clergyman. His father laid the foundation of his education, by instructing him in the elements of the Latin tongue, geography, \&c. He had now nearly completed his tenth year, and his paternal instructer saw the necessity of adopting a more sytematic course of study. He resolved, for this purpose, to send him to the grammar-school in the adjacent town of Wexicoe.

"In 1717, Charles parted from his parents, and his garden, and all his favourite haunts in field and wood, 
and set out for Wexicoe, where he was entered as a scholar. He did not, in this new situation, relinquish his former pursuits : on the contrary, he devoted to them every interval which could be obtained from his school-studies. On holidays, no pupil was found so little at home as Linnæus. In fact, since the truth must be told, he took more delight in gathering and examining plants, than in learning his phraseology or writing his themes. Fortunately for him, the rector of the school, whose name was Lanmerius, was a lover of botany: he soon observed the talents exhibited by the young Linnæus ; and while Charles's schoolfellows considered bim a vagabond truant, who wasted his time in idle wanderings and useless occupations, the rector formed a high and wellfounded opinion of his genius and merits. In this manner he passed seven 
years. During this period he had outstripped all his companions as a botanist and naturalist, but, unfortunately, he had made little proficiency in some of those studies which were intended to qualify him for the sacred calling. In his seventeenth year he left the grammar-school, and was received in the superior college at Wexicoe. Here the deficiencies, before alluded to, became more obvious ; and the slowness of his progress at length induced some of the professors to complain of him to his father, and to send him home with unfavourable testimonials. His parents were overwhelmed with sorrow and disappointment. Linnæus, with filial obedience, professed his readiness to pursue the study of divinity, if they still desired it; but, at the same time, avowed his disinclination, and total unfitness for the sacred office. They thought it in vain to press the point fur- 
ther; and since their son could not become a minister, they saw no resource but to apprentice him to some useful trade, that he might at least have the means of procuring a livelihood, which they beliesed the study of natural history would never secure him. And now, Henry, imagine the poor youth receiving the final decision of his parents to bind him apprentice - to what trade, think you? Alas ! to that of a cobbler ! It was, indeed, an honest calling. But only think of the young naturalist, exchanging his wild wanderings for close confinement to a cobbler's stall ; and the fragrance of flowers, for the perfume of shoemaker's wax.

From this sad predicament he was rescued by the kindness of Dr. John Rothman, professor of medicine in the college of Wexicoe. This gentleman c* 
had been early attracted by the unusual degree of penetration and knowledge evinced by Linnæus; and when he heard of his father's determination to remove him from college and bind him to a trade, he hastensd to prevent a measure so unfarourable to the happiness of his young favourite, and so ill suited to his talents. $\mathrm{He}$ addressed himself to the father, setting forth his son's diligence, and his peculiar qualifications for the study of physic and botany. He entreated him to reconsider the subject, and not to exclude his son from a profession, in which, with his singular talents, he could not fail of success. These encomiums could not but be highly gratifying to his parents, and probably contributed, as much as the liberal offers of Rothman, to incline them to adopt his plan. This generous friend enforced his arguments by a proposition too kind and 
well-timed to be refused. He offered to receive the young student into his own house, during the remainder of the scholastic term ; to provide him with every necessary ; and to instruct him himself in the elements of medicine. His parents at length gave their consent. With great relictance they had relinquished the fondly-cherished hope of seeing Charles in the church ; and endeavoured to console themselves, by dedicating their second son, Samuel, now in his seventh year, to the sacred office. But Samuel soon began to follow the example of his brother, and to show that he preferred flowers to books of divinity. Alarmed at these symptoms, and fearing lest the love of nature should again interfere with her wishes, his mother sought to suppress the rising inclination ; and for this end, forbade his gathering flowers, or even entering the garden. She could not, 
however, eradicate a propensity so deeply implanted in his breast. Although he finally entered the church, and, after the death of his father, succeeded to his living, natural history continued to be his favourite pursuit, and in one branch of it he became eminent as an author. He published a work on bees, which was much approved, and which procured for him the appellation of Bi-kung, or king of the bees. To return to his illustrious brother.

He found in the house of Rothman such advantages as he had never before enjoyed. Hitherto, his only opportunities for procuring knowledge on the subjects which peculiarly attracted his attention, were the short intervals stolen from other employments, and secretly devoted to his favourite study. Now he was at liberty to pursue his career, unfettered by other engagements. 
In addition to the college routine, Rothman gave him instructions in private; and facilitated his progress still more, by allowing him the use of his well-furnished library, where he found inexhaustible resources. The works of naturalists and men of science were, to the ardent mind of young Linnæus, as fountains of water springing up in the desert. Joyfully did he drink of the streams of knowledge which they supplied; and Rothman soon saw his pupil rise far above all his fellow-students in botanical research. The further he advanced, the more he was enamoured by the charms of nature ; and both at Wexicoe, and at his father's residence, when the recess at college led him there, he continued to add to his collections of plants and insects. In employments so consonant with his inclination, three years passed swiftly away; and the time approached 
when he must separate from his kind patron, and leave the college at Wexicoe for the university. He had much to regret, in quitting the hospitable dwelling of Rothman; but pleasant prospects unfolded before him at the university, and with the buoyant feelings of youthful hope he set out for Lund. Of the two universities of Sweden, Upsal and Lund, the limited fortune of the elder Linnæus obliged him to fix on Lund. He had there a friend and relative in professor Humerus, who had promised his support and interest to the young student. It was with a slender purse that Linnæus began his journey to Lund. It was not in the power of his parents to advance much for him ; and probably they did not yet think so favourably of his plans, as to be willing to promote them to the utmost of their power. But if he had little money, he had an inexhaustible store of spirits and 
mental energy; and his kinsman, the professor, had promised to be his supporter and patron.

Arrived at Lund, he hastened to present himself to Humerus. But a stunning blow awaited him:-his promised friend was no more, and the last duties had just been paid to his lifeless remains. Disconsolate and distressed he returned to his lodgings, to lament over the downfall of his hopes. Alone in Lund, without one person to lend him countenance in the university, and with small means of support, there was now nothing further to depend on but the industrious exertion of his own talents; and he therefore prepared himself to make every effort in his power. Solitary and and unfriended, he entered on the prescribed course of study. Soon, however, he attracted the notice of Killian Stobbrus, professor of physic and botany in the university. He was a learn- 
ed and scientific man, and his lectures proved highly valuable to Linnæus. The professor observed the attention of the young student; and, delighted to behold the rapid progress he made, he began to take him more particularly under his protection. At length he became acquainted with his indigent condition, which indeed his appearance had led him to suspect. Touched with the sorrows and difficulties of his pupil, like the generous Rothman, he offered him accommodation in his family free of all expence. The proposition was thankfully accepted; and, with a heart glowing with gratitude, he became an inmate in the house of Stobbæus. Here all his love of science was fostered.

It was now that he began to keep a regular herbal; a plan, of which he soon discovered the importance. It induced him to be more diligent in collecting flowers, and more careful in exam- 
ining their internal structure, on which he was hereafter to found his botanical system.

Many were the excursions he made to enrich his herbal, and to add to his collection from the animal kingdom. In one of these expeditions he was stung by a venomous worm, not uncommon in Sweden, to which he afterwards gave the name of Furia Infernalis. As he was far in the country when the accident happened, the poison affected his whole frame before it was possible to obtain medical aid. To such extremity was he reduced by its effects, that his life was despaired of ; but the skill of Stobbæus saved him. This circumstance, instead of damping his courage, seemed rather to serve as a stimulous to prosecute his researches with increased ardour. But it was to the vegetable world he was the most strongly at- 
tracted. In the library of Stobbrus he found an extensive collection of botanical works. Anxious to read them all, and finding the day did not allow him sufficient leisure, he procured volume after volume by stealth, to study them at night as long as the light of his lamp lasted.

Stobbæus by some means heard of his vigils ; and knowing that his young friend was rather of a convivial turn, it occurred to him that he might possibly have been tempted to invite the upper servants into his room to play at cards. He determined to see for himself : resolving to dissuade him from so incorrect and ungentlemanly a practice. He accordingly entered the apartment of Linnæus at a very late hour. But what was his surprise and delight, to find his young friend, not surrounded by companions unsuited to his education, but entrenched in the works of the 
greatest botanists, such as Cesalpinus, Bauhines, Tournefort, \&c.

Charmed with a discovery so satisfactory to his feelings, he became more warmly attached than ever to his pupil; and treated him with increased liberality and kindness.

But it is time I brought my letter to a conclusion; and as we leave our hero in a home so much to his taste, I am the more willing to do so. You may expect to hear from me as soon as I return from the journey which your brother has told you we have in contemplation.

Your ever affectionate Father, 


\section{LETTER III.}

Mx dear Boy,

IF the difficulties with which

Linnæus had to struggle, serve to excite an additional feeling of interest towards him, I need not fear that this feeling will decline at present. We left him peaceably pursuing his studies at Lund, under the favourable auspices of professor Stobbæus. But Linnæus was not one who would rest contented in the lap of luxury, when the hope of increasing his knowledge called him to other scenes. The university of Upsal furnished him with such an inducement to quit Lund and his kind protector there. He was well aware that in going thith- 
er he should draw upon himself a complete reverse of circumstances ; and had every reason to suppose, that he should find himself in nearly as destitute a condition as he had done at Lund during his early attendance on the university. But every objection of this kind gave way to his love of study: and having obtained the consent of his parents, he took his departure from Lund, and reached Upsal in the autumn of 1728 : being then little more than one and twenty years of age.

His intellectual stores were increased; but he entered Upsal, as he had entered Lund, with a purse scantily filled, and with little skill in the management of his contracted finances. He commenced his studies, however, with great energy; and gave himself little anxiety about the means of support. The professors under whom he was to study 
were Olaus Rudbeck, and Roberg, both old men. This circumstance, which at first seemed unfavourable for him, proved advantageous in several instances, as you will hereafter see. But for the present, clouds and darkness seemed to rest on his path.

"Ah? who can tell how hard it is to climb

The steep where Fame's proud temple shines afar f

Ah! who can tell how many a soul sublime

Has felt the influence of malignant star;

And waged with fortune an eternal war ?"

The greatest naturalist and botanist in Sweden at that time was Olaus Celsius ; first professor of divinity, and afterwards head of the chapter of Upsal. Linnæus had hoped to gain much from the learning and experience of this great man. In this he wasat first completely disappointed, as, on arriving at Upsal, he found that Celsius had been called to Stockholm on official business. Ardent and indefatigable as erer, but 
growing poorer every day, he passed a year in close study. At the expiration of that period he found himself reduced to a deplorable state of poverty : all his money was expended; he had no hope of a supply from home; nor had he any cheering prospect of future support, to mitigate the feeling of present misery. $\mathrm{He}$ found some relief from his distress in the kindness of his fellow-students, to whose tables he was occasionally invited. Yet even with the assistance of this casual benevolence, it was not without difficulty that he procured from day to day the mere necessaries of life. The deficiencies of his wardrobe, were supplied by the cast-off clothes of his more fortunate companions. So great was his poverty, that he could not even purchase a pair of shoes, and was compelled to patch those which were given him by his acquaintance, with pieces of card stitched in with thread made from 
the fibres of the bark of trees, in order to enable himself to go out and collect plants: thus putting in practice a branch of the very trade to which his father had proposed to bind him.

Imagine him, Henry, in this predicament; scantily supplied with food and clothing; uncertain even where tomorrow's meal might be found. He does not fold his hands and sit down to sigh over his sorrows. He was too much in earnest in the course he had traced out for himself, to be checked by the first obstacles he met with; nor could

"Chill pesury repress the noble rage, Nor freeze the genial current of his soul."

In the midst of these depressing circumstances, he continued his daily researches, and his nightly studies, with unremitted ardour. He had long suspected that the botanical theory which then prevailed was very incorrect and 
unscientific; and, confirmed in this opinion by every observation he made, he revolved in secret that new plan of botanical arrangement which was to displace the long-established system, and form an era in the science of natural history. "Methinks," says a Swedish writer, "Linnæus saw Flora in all her beauties, on a throne; he saw her holding forth a wreath to crown his head. All nature in her magnificence bade him draw nearer; but he saw the whole, as it were at an immense distance. He was obliged to penetrate the labyrinth of Drdalus, to seek the thread which could guide him to the right path, through so many wanderings."

It was indeed a labyrinth he had to tread, both as it regarded his outward affairs, and the difficulties and intricacies with which the errors of those who had 
preceded him had surrounded his favourite science. A less ardent mind might have sunk under the weight of so many opposing circumstances; but he marched firmly on, though not insensible to the roughness of his path. He felt his, trials keenly, whilst he bore them manfully; and when in a more prosperous period of his life, twelve years afterwards, he entered on the office of professor, in his installationspeech he returned public thanks to the Almighty for having so wonderfully supported him under all his difficulties, and eventually relieved him from their pressure.

His poverty and distress had risen to the greatest height, when once more the scene brightened. Celsius, whose acquaintance and patronage he so much desired, returned from Stockholm. He soon came to the botanic garden. Linnæus was there, and Celsius, hearing 
him describe the plants with peculiar accuracy and intelligence, entered into conversation with him, and quickly discovered that the young stranger had examined the subject with no common degree of care and attention. Pleased with what he had seen and heard, he made further enquiries about him ; and soon became acquainted with his merits, and with his distresses also. And now another kindly heart was warmed in his favour; and Celsius, as Rothman and Stobbæus had done before, offered him an asylum in his house, where he might pursue his studies free of expense. Here, as in the former instances, he found a well-stored library, and a kind and intelligent host, willing and able to assist him in all his researches. He had at the same time, the gratification of making himself useful to his patron by the help he gave him in preparing for the press a work on the trees 
and plants mentioned in the Scriptures, on which he had been for some time engaged. Celsius treated his inmate with the tenderness and indulgence of a parent ; and of all the benefactors of Linnæus, there was not one on whose kindness he dwelt with such fond and grateful affection. Indeed, kindness so well timed, succeeding to so much neglect and misery, must have been to the heart of Linnæus like the oil and wine of the good Samaritan.

It is difficult to ascertain how long he remained with Celsius; but probably until a more eligible offer was made him, arising out of the following circumstances. In the summer of 1730 , Linnæus composed a little treatise on the subject of his favourite study, which, though only in manuscript, attracted considerable attention in the university. Olaus Rudbeck, then professor of botany, heard of this treatise; and hav- 
ing obtained a sight of it, was struck with the acuteness of observation it exhibited. A more intimate acquaintance with the character and attainments of the writer confirmed him in the high opinion he had formed of the young student, and determined him to take him under his immediate patronage. He received him into his house; he advanced him in his academical course; and chose him as his assistant lecturer in the botanic gardens: an office which, at the advanced age of seventy, he found too laborious to discharge alone. It was no slight honour for a young man of three-and-twenty, to be selected as the representative of a venerable professor. He filled his new office with great approbation. The novelty of his ideas, and his animated style of lecturing, charmed all his hearers; and the applause he met with produced 
its effect in stimulating to yet greater industry and exertion. Meanwhile, his plan for reforming the botanical system was silently advancing; and he wrote several treatises on the classes and genera of plants, which at a later period were published, and served to diffuse his opinions more widely.

His talents were now justly appreciated by those around him. In the year succeeding that in which he became lecturer to Rudbeck, he was chosen by a literary society at Upsal to make a tour of philosophical enquiry in Lapland; a part of the Swedish dominions which, until that period, had never been explored by a naturalist. Celsius and Rudbeck, who were leading members of the above-mentioned association, united in recommending him as the most suitable person for such an undertaking. 
And now, Henry, I suppose you picture to yourself our hero, much delighted with the prospect of an expedition, which was to give him an opportunity to pursue his researches in a country hitherto little visited. A tour in Lapland, however, under the circumstances in which Linnæus undertook it, would have presented little temptation to a less adventurous mind. The perils of the Lulean desert were neither few nor trifling ; and the sum provided to defray the expenses of the journey, afforded no means of solacing the difficulties of the traveller by indulgences. The purse presented him for this purpose, by the society whose mission he was to execute, contained no more than one hundred Swedish platens, or 31 dollars, at the utmost. With this sum he traversed a wilderness region for six months; and even economized so well as to sêcure from it enough to purchase a com- 
plete fur-dress. He accepted the proposition of the society, in the autumn of 1731 ; but as it was vain to think of commencing a journey in the Siberia of his country before the approach of spring, he passed the winter in making preparations, and in visiting his friends at Lund, and his parents, who were now reconciled to his views, and approved of his plans. This journey will furnish a subject for my next letter, which you may expect shortly.

In the mean time, whenever the map of Sweden meets your eye, it may serve to remind you at once of the "Swedish sage," and of

Your affectionate Father. 


\section{3}

\section{LETTER IV.}

¿Now then, my dear boy, we will set out on our Lapland tour; but we must not allow it"to take up a great deal of time, as much fof our hero's history still remains untold. Linnæus has described the whole of his equipments for this journey with much amusing minuteness of detail ; but whether from a spirit of dandyism, you must judge from the description of this singular travelling costume. He wore a light coat of linsey-woolsey, lined with red shalloon, having a collar and cuffs of shag; leather breeches, a round $\mathrm{E}^{*}$ 
wig, a green leather cap, and a pair of half-boots. He had a hanger at his side ; and he carriel, besides, a small fowling-piece, and an octangular stick, graduated for the purpose of measuring. His luggage was contained in a small leathern bag; and consisted of the following articles : one shirt, two half-shirts, two pair of false sleeves, an inkstand, pen-case, microscope, and spying-glass ; a gauze cap, to protect him from gnats; a comb ; a parcel of paper, stitched together for drying plants; his journal, and two or three other manuscripts.

You will not admire his taste in dress, I dare say ; but you cannot fail to be pleased with the cheerfulness with which he enters on his tour, though so slenderly provided with the means of prosecuting it with ease and convenience. With his usual mental energy and light-heartedness of feeling, he sets 
forth, commencing the first day's record of his journal in the following words, which are written in so pleasant and characteristic a style, that I cannot withhold them from you without injustice to the writer. "I set out alone from the city of Upsal, on Friday, May 12th, 1732, at eleven o'clock, being at that time within half a day of five-andtwenty years of age. At this season, Nature wore her most cheerful and delightful aspect ; and Flora celebrated her nuptials with Phøbus.

'Omnia vere vigent et veris tempore florent,

Et totus fervet Veneris dulcedine mundus.'

' Spring clothes the fields and decks the flow'ry grove, And all creation glows with life and love.'

"Now the winter corn was half a foot in height, and the barley had just shot out its blade. The birch, the elm, and the aspen-tree began to put forth their leaves. The lark was my com- 
panion all the way, flying before me quavering in the air."

Thus, gay as the bird whose song cheered his path, the traveller passed on: now charmed with the scenery, and now delighted by the discovery of some rare plant or insect. In order to economize as much as possible, he travelled alone, except where the intricacies and difficulties of the road made it neeessary to have a guide. As he penetrated into the forest district, and approached the Lapland Alps, he found his course impeded by the thick growth of trees, whose intermingled branches presented a barrier, rendered yet more formidable by the prostrate trunks of the largest pine-trees, which recent storms had brought to the ground. Besides this, the country was intersected in every direction by streams, now greatly swollen, which were to be crossed, almost at the peril of life, from the 
ruinous state of the bridges. Sometimes he had recourse to riding on horseback ; but,unfortunately, the steed was often as ill-conditioned as the road: a meagre stumbling animal, accoutred with an unstuffed saddle, and no bridle ; the place of this last article being supplied by a rope, which was fastened round the under jaw.

$\mathrm{He}$ had reached the southernmost province of Lapland, called Umea Lapmark, by the end of May ; but the tardy spring had not yet visited that remote district. Every one exhorted him not to persist in prosecuting his journey. He was told it was impossible to proceed far in the tract of country to which his course was directed, whilst the roads were inundated, and the rivers swollen by the melting of the winter's snows, as they always are during the summer months. Linnæus, however, was not to be discouraged; 
and having waited awhile for more favourable weather, he recommenced his wanderings. A few solitary huts seattered over a wide district, were all the human habitations he was likely to meet with. These were inhabited by a race of poor but contented peasants, who are generally kind and hospitable. Linnæus esteemed himself happy if, after a day of fatigue and exhaustion, he could reach one of their dwellings, and obtain food and shelter for the night, though both were of the humblest description. The huts were usually filled with smoke, excessively filthy, scented with fish, and infested with tormenting insects. The food chiefly consisted of fish, and rein-deer's milk in various forms: bread was a luxury rarely to be met with. Ten years afterwards, alluding to this journey, in a speech he delivered before the university, he protested that he had under- 
gone more danger and privation in that solitary expedition to the northern frontier of his native land, than in all his subsequent travels in foreign countries. I have omitted to mention one accommodation to which he had recourse, in the use of a boat wherever the rivers were navigable. The natives, an active and hardy race, glide down their streams in small light boats, until they reach a part where their course is interrupted by rocks or falls, where the rapidity of the stream renders it unsafe to proceed. When the Laplander reaches such a spot, he lands, drags the little vessel to shore, and placing the two oars longitudinally, so as to cross the seat, turns it bottom upwards over his head; the oars resting on his arms, and enabling him to carry it steadily. Thus equipped, he marches over hill and dale at a swift pace, apparently quite unencumbered by the 
burden. Whenever it was necessary for the guide to adopt this plan, Linnæus was of course obliged to take charge of his own luggage, which, light as it was, added to his toils. It should be recollected, too, that he was in a country where the protracted daylight tempts the traveller to proceed on his journey through many hours of the night, as well as the day, until his declining strength warns him to pursue more prudent measures.*

* The light of what is termed the " midnight sun," in countries approaching the North Pole, new and delightful as it is to the more southern traveller, often induces him to continue his journey through the night, till he adds to the usual fatigues of travelling, exhaustion from want of proper rest. Dr. Clarke has given an animated description of the enthusiasm with which himself and his fellow-traveller gave themselves up to the enjoyment of this protracted day-light, in those very districts through which Linnæus passed. They could not resist 
After himself and his guide had passed some days and greater part of the night, traversing on foot the worst roads imaginable, and wading through marshes often in the most violent storms of wind and rain, they found themselves, early one morning, on firm ground once more ; but with no human habitation in view, nor any track by which they might direct their course. They kindled a fire ; and Linnæus, perfectly

the pleasure of travelling on, night after night, beneath a light so new and beautiful, until they began to feel the painful consequences of overexertion, added to the oppressive effects of continued day-light on their eyes. "It could not be called twilight," observes Dr. C. " it was rather the glare of noon ; being reflected so strongly from the walls and houses, that it was painful to our eyes; and we began to perceive, what we had never felt before, that darkness is one of those benevolent gifts of Providence, the value of which, as conducive to repose, we only become sensible of when it ceases altogether to 
exhausted by fatigue, after wringing some of the wet from his garments, lay down, hoping to obtain some refreshing repose; but the gnats, which are particularly tormenting in that country, and the cold north wind which blew around him, chased sleep from his eyes. Meantime, his more hardy compaiion went in search of another guide ; and the traveller left alone, dispirited and exhausted in this desolate region,

return. There were no shutters to the windows ; and the continued blaze which surrounded us we would gladly have dispensed with, if it had been possible. When we closed our eyes, they seemed to be still open : we even bound over our handkerehiefs ; but a remaining impression of brightness, like a shining light, wearied and oppressed them. To this inconvenience we were afterwards more exposed ; and although use rendered us somewhat less affected by it, it was an evil of which we all complained ; and we hailed the returning gloom of autumn as a blessing and a comfort."

Dr. Clarke's Travels in Scandinavia. 
began to lament that he had ever commenced a journey so hazardous and toilsome. He even thought it probable that his former companion, unable to retrace his steps exactly, might never find him; and in this case he must expire from fatigue and want of food, and inability to proceed alone in search of a human dwelling.

At length, however, his guide returned, and with him a most extraordinary-looking person, whose appearance was such, that he was at first doubtful whether it was man or woman he beheld. It was in fact a woman of most unprepossessing aspect. She was very diminutive in stature; her face and neck were so shrivelled and embrowned, by living constantly in the smoke of a Lapland hut, as to resemble the skin of a toad rather than that of a human being; the hue of her dark sparkling eyes seemed deepened by the 
shade of her black eye-brows; and her long black hair hung in loose and wild confusion about her face. On her head she wore a flat red cap; a kind of tippet, two grey jackets, a petticoat of the same colour, fastened by a girdle round the waist, and a pair of halfboots, completed her costume. But if this untutored daughter of the Lapland wilderness had nothing in her appearance to attract admiration, she possessed a kindly heart, and was touched with compassion at the forlorn appearance of the traveller. "Oh! thou poor man!" she exclaimed, "what hard destiny can have brought thee hither, to a place never visited by any one before? This is the first time I ever beheld a stranger. Thou miserable creature! how didst thou come, and whither wilt thou go?" $\mathrm{He}$ entreared her to direct him how to continue his journey, with- 
out returning by the perilous road he had so recently passed.

"Nay, man," said she, "thou hast only to go the same way back again; for the river overflows so much, it is not possible for thee to proceed further in this direction. From us, thou hast no assistance to expect in the prosecution of thy journey ; as my husband, who might have helped thee, is ill. Thou mayst enquire for our next neighbour, who lives about a mile off, and, perhaps, if thou shouldst meet with him, he may give thee some assistance ; but 1 really believe it will scarcely be in his power." He enquired the distance to Sorsele. "That we do not know," she replied; "but in the present state of the roads, it must be at least seven days journey, as my husband has informed me."

He was greatly in want of food; but 
she had nothing with her, except a single fresh fish, as she called it, which was literally alive with maggots. The sight of it was so disgusting to - Linnæus, as to take away all desire to touch it. He asked if she could not furnish him with some dried rein-deers? tongues. She had none. Had she no rein-deer cheese? "Yes, but it is a mile off," was the discouraging answer. "If it were here, would you allow me to buy some?" he enquired, knowing that their very scanty supply of food made them sometimes unwilling to part with any, even at a high price. The good woman replied, "I have no desire that thou shouldst die in my country for want of food."

She then undertook to show them a path, by which they might avoid some part of the road they had passed in coming; and having led them to her hut in the forest, she sold them one of 
the three cheeses she possessed. They then took their leave of her, and pursued their way; Linnæus inwardly resolving that he never would again visit so deplorable a spot. In the midst of the difficulties of his route, the spirit of investigation did not desert him; and he continued to make minute observations on birds, insects, and flowers. And here I must remind you, that, far from magnifying the toils of the way, or dwelling on passing inconveniences, the joyous feelings of a heart gratefully alive to every advantage, break out continually in the simple journal which he has left us of this tour.

On the 24th of June, a few weeks after the above adventure, he writes: "Midsummer Day.-Blessed be the Lord for the beauty of summer and spring; and for what is here in greater perfection than almost any where else in the world-the air, the water, the 
verdure of the herbage, and the song of birds."

In another place, after ascending and descending some of the Lapland alps, he says, "When we arrived at the plains below, how grateful was the transition from a chill and frozen mountain, to a warm and balmy valley! I sat down to regale myself with strawberries. Instead of ice and snow, I was surrounded with vegetation in all its prime. Instead of the blustering wind so lately experienced, soft gales wafted around us the grateful scent of clover and various other plants. In the earlier part of my journey, I had experienced a long-continued spring, whose steps I pursued as I ascended the Lapland hills; then unremitting winter and eternal snow surrounded me : summer at length was truly welcome. Oh! how most lovely of all is summer here!"

It was in speaking of this very tour 
that he afterwards declared, that, having once sustained the toils of travelling, he buried in oblivion all the dangers and difficulties he had encountered, and considered the invaluable fruits he had reaped from his excursion a full compensation for every toil.

At Upsal he had chosen the motto, Tantus amor Florum, (thus great is the love of flowers, ) and never did any body. select for himself a more appropriate one.

"Surely," says a Sweedish writer, "he must be a faithful lover of Flora, who suffers so much in her service, and is contented with a favourable smile of his beloved one; as Linnæus was with a plant growing on the brink of some steep waterfall, to which he climbed at the peril of his life; or with some unknown moss, concealed in profound caverns or clefts of the rock."

Having completed his tour, which he extended to the alpine hills separating 
Norway from Sweden, and from thence to the shores of the Frozen Sea, he returned to Upsal in the autumn. The object of the expedition was found to be completely fulfilled.

Although Lapland is a country poor in plants, Linnzus discovered upwards of a hundred, which were either entirely unknown or undescribed before. Birds and insects, likewise, were added to his list, and their peculiarities minutely marked. At the same time, the manners and customs of the people were recorded with an accuracy before unknown. The Royal Academy of Science received his report very favourably, and inserted it in the annals of their transactions. As an additional proof of their esteem, they enrolled him a member of their body. Thus, some increase of knowledge acquired in his travels, and the honour of being elected an academician, were the only rewards 
he obtained. The termination of the tour brings my letter also to a conclusion. For the present, therefore, I take my leave of you ; and wishing you all success in your botanical researches,

\author{
I am, as ever, \\ Your affectionate Father, \\ C. $V$.
}




\section{LETTER V.}

\section{My dear Henry,}

ThE honours earned by the naturalist in his late tour, raised up a bitter enemy in a young student of the name of Rosen : so truly does envy follow merit. Linnæus had not taken his degree, and was therefore excluded by an old law of the university from the advantage of delivering public lectures. This restriction would not have been enforced in his case, but for the unfriendly offices of Rosen; who, having been chosen anatomical and medical professor, looked upon Linnæus as a formidable rival, and resolved to crush him if possible. Unfortunately, he took 
his measures so well, as to succeed in obtaining a decree, forbidding the offending lecturer to proceed in his undertaking.

This stroke seemed, for a time, a death-blow to the hopes of Linnæus ; as his only means of support was the profit arising from his lectures. Borme away by the violence of his feelings, he followed Rosen, as he left the senatehouse after the decree had passed, and drawing his sword, would have run him through the body, had not the bystanders interfered, and wrested the weapon from the infuriated student. This violent assault was not likely to pass unnoticed ; and Rosen laid a complaint against his rival, for so gross a violation of the public peace. He was near obtaining a decree of proscription against the offender, which would have prevented his ever appearing again at 
Upsal. The friends and protectors of Linnæus, with Celsius at their head, warded off this blow, and he was spared from any legal punishment. His revengeful feelings, however, took such complete possession of his mind, that he was for a long time in a wretched state of mental tumult.

At length, awaking once at midnight, he was suddenly struck with horror and consternation, under a sense of his sinfulness in harbouring these wrathful and malevolent passions in his heart ; and he proved the sincerity of his repentance by seeking to overcome them, and by abandoning his vindictive projects.

The tempest of his mind was happily calmed, but his external circumstances were as unpromising as ever. He was, as we before observed, unable to proceed in lecturing, unless he first obtained a degree. This could not be 
done, without incurring expenses such as his slender means would not allow him to risk. His friends endeavoured to obtain for him an office in the university of Lund, from which he might derive some emolument; but their efforts in his favour failed of success.

His case now seemed almost hopeless: indeed there appeared no way of extricating himself. But the ardour of his mind and the buoyancy of his spirits did not forsake him. He met his difficulties without murmuring or dismay, and.still looked forward hopefully to brighter days. Many of his former pupils witnessed his trials with concern; and the patience and fortitude with which he bore them, raised him yet higher in their esteem.

Affairs had remained in this state some months, when several of these young men resolved to make a minera- 
logical excursion in the mountainous districts of the kingdom ; and invited Linnæus to become their guide and instructer. You may believe it was no unwelcome proposition to him. A scientific tour, in company with those who had learned to love and esteem him, could not fail to be very agreeable ; at the same time that the temporary assistance it afforded him in a pecuniary point of view, was worth his consideration.

They travelled together into Dalecarlia. At Fahlun, the capital of that province, they were introduced to baron Reuterholm. This nobleman was governor of the province, and director of the rich copper-mines in that neighbourhood. He was passionately fond of the study of natural history ; and occupied his leisure in scientific researches. He was struck at once with the uncommon talents of Linnæus ; and 
the acquaintance thus begun, ripened into a warm friendship, which became the source of important events in afterlife.

He seems to have waited but a short time, after fulfilling his engagement with his Upsal friends, before this new friend furnished him with employment. The baron had two sons, whom he was desirous to send on a scientific tour to explore the mines in Norway, as well as to make themselves thoroughly acquainted with those in the province of Dalecarlia. He fixed on Linnæus as their travelling tutor. Several other young men joined the party ; and they had a pleasant and interesting journey. Each of the young travellers fixed on some particular branch of mineralogical knowledge, which he was more especially to study ; and they all returned home, highly satisfied with their expeG* 
dition and with the information they had obtained.

This tour completed, Linnæus had again to consider what plan he should adopt. At Upsal, it was quite certain he could not succeed under existing circumstances : he therefore determined to fix himself for a time at Fahlun. Here he took pupils, and delivered lectures. He had a sufficient number of pupils to answer his present purpose ; and his lectures attracted much attention, especially those on mineralogy ; the mines in the neighbourhood rendering this subject particularly interesting to the inhabitants. As yet, his labours did not procure him any great increase of wealth : but a little satisfied him ; and here, as in other places, he acquired fresh fame by his talents ; while, by his good conduct and amiable manners, he added to the number of his friends.

But amongst his newly formed ac- 
quaintance at Fahlun, there was one individual who possessed more attractions for him than all others. This was a young lady, the daughter of a physician of the name of Moræus. In a letter to his friend, the celebrated baron Haller, he has detailed some of the circumstances of this connexion.

After informing his friend that he had settled at Fahlun, and commenced lecturer, he proceeds :- "The physician of that place passed for a rich man : considering the poverty of the province, he might justly be deemed opulent. His name was Moræus. He was eminent for his learning and skill : physic, especially practical medicine, was the science which he esteemed and preferyed above all others. He grew fond of me : I visited him frequently, and always met with an amicable reception. He had two daughters. Sarah Elizabeth, the eldest, was a beau- 
tiful girl : a certain baron had paid his addresses to her without success. I saw her; was amazed, smitten, and fell in love. My caresses and representations won her heart. She promised her consent, and vowed to be mine. But as a poor young man, I was much perplexed to ask her of her father. At last I ventured. Moræus consented, and refused. He loved me, but not my uncertain and adverse fate. $\mathrm{He}$ finally declared that his daughter should remain unmarried three years longer, and at the expiration of that time, he would give his ultimate decision."

It appears that Moræeus thought, as the father of Linnæus had done, that botanical and mineralogical studies were little likely to secure fortune, whatever fame might await the student. He therefore advised him to apply himself more completely to the study of practical medicine, and urged him to procure 
adoctor's degree. Want of money rendered it impossible for him to take the necessary steps for securing this advantage. He made every effort to save a sum sufficient, from the profits his pupils afforded him. But these were so little beyond what was required to supply his daily necessities, that it would have been very long indeed before he had economized enough; and he must still have remained unable to go in search of his degree, had he not been assisted by his Elizabeth.

Out of the stipend allowed her by her father, she economized so much as to lay by a hundred dollars. This sum she gave her lover, to aid him in an undertaking in which they were both so much interested. This, and the fruits of his own labour, furnished a stock, sufficiently limited indeed, but large enough to justify his entering on the undertaking. 
At this time, it was the custom of the Swedes to travel into foreign countries to take their degrees. Holland was the country most in repute with medical students; and there the Swedish physicians generally graduated. Among the Dutch universities, that of Harderwyck was the least expensive, and therefore best suited to the straitened finances of Linnæus.

The following spring, he set out on his travels; and after various adventures, reached Harderwyck; where he succeeded in obtaining a degree, in June, 1735 , being then in his twentyeighth year.

His talents and acquirements ought certainly to have secured him this honour at a much earlier period. The great business of his journey was now completed; but he was unwilling to return home, without reaping some further advantage from his travels. 
From Harderwyck he passed on to Leyden. Taking up his abode there for some time, he formed an acquaintance with many celebrated scientific men; and, encouraged by their approbation of his views, published his first work, the Systema Naturce.

Among the advantages arising from the publication of this volume, it served to draw on him the notice of the great physician and botanist, Boerhaave; at that time so celebrated a person, as to have received a letter from China with this address simply, "à l'illustre Boerhaave, Medecin en Europe."

So numerous and important were the visiters of various nations who sought his acquaintance, that he had often as crowded a levee as if he had held a little court ; and ambassadors, princes, and even so powerful a monarch as Peter the Great, had been obliged to 
wait several hours in his antichamber before they could obtain admittance.

Linnæus, therefore, esteemed himself particularly fortunate when he had received an invitation from Boerhaave ; who, having read his work, had become eager to make acquaintance with an author whose views, on a subject he had long studied, were so new and striking. Linnæus presented himself at the hour appointed ; and the conversation which followed raised him still higher in the estimation of the venerable Boerhaave, who was delighted with the talents and acquirements of the young physician.

This introduction was productive of most important consequences. Boerhaave advised him not to quit Holland; assuring him that his talents could not fail of receiving their due reward in that country. Linnæus, however, found his little stock of money reduced 
too low, to allow of any prolonged stay. He proceeded, therefore, to Amsterdam ; intending from thence to embark for Sweden, and by this means return home at the least possible expense.

But here the friendship of Boerhaave came to his aid. He had given Linnæus a letter of introduction to John Burman, professor of botany at Amsterdam. This secured to him a friendly reception from Burman; who, on his part, was as much pleased with the northern student as his friend had b een. He was at that time overwhelmed with business, and was particularly e arnest to complete a description of the plants found in the island of Ceylon; a work which had for some time been on his hands. He quickly perceived how useful such an assistant as Linnæus would be, in the prosecution 
of his undertaking. At the eonclusion of a long botanical conversation he said, "Will you help me in my CeyIon collection? Will you, and can you, stay at Amsterdam ?" The traveller frankly confessed that his poverty rendered a long residence in Amsterdam impossible, however agreeable it might be to his inclinations; and that he was under the necessity of proceeding home with as little delay, and at as little expense, as possible. This difficulty Burman instantly removed, by assuring him that, if he consented to stay, he would gladly receive him as an inmate in his house, free of all eharge.

As he had no settled plans, or certain prospects of success in Sweden, it seemed advisable to accept the present offer ; since it might hereafter lead to something more eligible. His situ- 
ation at Burman's gave him valuable opportunities of increasing his knowledge ; and under the roof of his new friend, occupied with pursuits so congenial to his taste, the winter season glided pleasantly and rapidly away. On the approach of spring, he was again on the point of setting out for Sweden, when the kindness of Boerhaave once more interposed, and prevented his return home by recommending him to another patron.

The Duteh merchants and burgomasters had long been remarkable for their love of gardening, and for the large sums they expended on rare plants. Among these munificent disciples of Flora, was George Cliffort, burgomaster of Amsterdam, and one of the directors of the East India Company. His fortune was princely; and his connexion with these traders in the 
88 LIFE OF LINNACS.

Eastern Ocean, gave him particular opportunities for obtaining plants and other natural curiosities, from the islands and continent of Asia. In fact, he collected treasures from all quarters of the globe, to fill his museum and enrich his garden at Hartecamp ; a villa which he possessed near Haarlem. He spared no expense in the purchase of these valuable articles ; had succeeded in making a very large collection of plants and natural curiosities ; and now began to feel the necessity of having some person to arrange them in scientific order for bim.

While uncertain on whom to fix, he went one day to Leyden to visit Boerhaave, who was his physician and his friend. In the course of conrersation, Boerhaave said, "Shall I give you ? some good advice? You have plenty of every thing : yet there is one thing 
you want to render your life happy. You are accustomed to live high ; hence it is that you are so frequently troubled with hypochondriac complaints. You must keep a physician of your own, to prescribe and order your diet, and to take daily care of your health : in cases of a more serious nature, he may consult me."

"Well proposed," replied Cliffort; "but where shall I find such a clever: and skilful man ?"?

"This I shall make my own business," said Boerhaave : "I know a young Swede who is now at Amsterdam; he is the person I shall recommend, as the best to answer your purpose. Besides, he is also an excellent botanist : and he will arrange your garden at Hartecamp."

Cliffort was delighted with this plan: it seemed calculated to meet all his $H^{*}$ 
wants and wishes. Burman and Linnæus were invited to Hartecamp. The Swede more than equalled the expectations of Cliffort, who was charmed. with his new acquaintance. Terms were soon proposed and accepted; and the spring of this year saw Linnæeus established as an inmate at Hartecamp with a salary of one thousand florins per annum.

This sum, though $\mathrm{f}$ believe you will find it to be little more than four hundred dollars, was an income far greater than he had ever before enjoyed. He had accepted the offer with joy and gratitude ; and he found in his new situation every advantage for the prosecution of his own private studies, as well as for the completion of the task undertaken for his employer. Here was a splendid library; plants and natural curiosities from every quarter 
of the globe ; and a munificent patron, ready to procure any thing which might be wanting. All this was combined with the luxuries of life ; and every enjoyment was heightened by the society of the most intelligent and scientific men in Haarlem, Amsterdam, and Leyden.

I In this paradise, as he ealled it, surrounded by social and intellectual advantages, he classed his flowers and his insects ; and studied and wrote. Here he had leisure to mature the plans which had long occupied his mind ; and from this retreat he sent out to the world many of his most valuable works.

And here we will for the present take our leave of him. Like the students and professors from Leyden, and Haarlem, and Amsterdam, I can make only passing visits to Hartecamp. My 
92

LIFE OF LINNAEUS.

duties call me away to other scenes; but I shall be glad to return to those flowery shades with you, at my first leisure moment.

Ever, my dear boy,

\section{Your affectionate Father,}

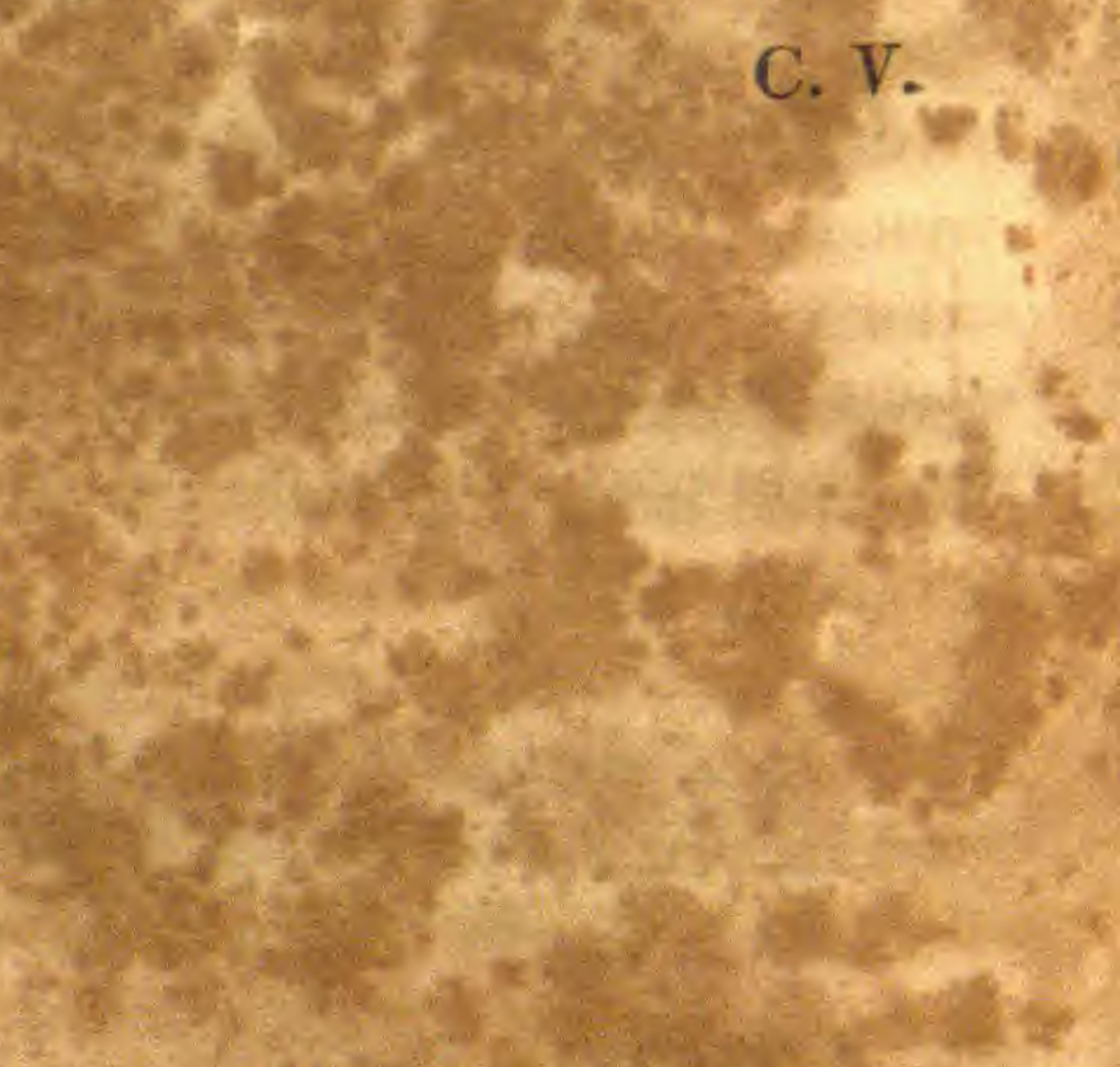




\section{LETTER VI.}

sy Mear Henrt,

WE will now repair to Hartecamp, to see how it fares with Linneus. The spring had passed most pleasantly away, and the summer was advancing, when he found he had nearly completed the task assigued him, and placed the garden and museum in scientific order. Cliffort now proposed to him to undertake, at his expense, a voyage to England, in order to establish connexions for him with naturalists in that country, and to procure for him some of the beautiful North American shrubs; which were even then culti- 
94 MIRE OE LINNAES.

vated in the nurseries of London and Oxford, although as yet they were not generally dispersed throughout Europe. There was no country Linnaus more ardently desired to visit than England, and he gladly acceded to the wishes of his patron. Cliffort, howvever, was become so attached to him, that he stipulated for as short an absence as the business he went on would admit.

Linnaus set out on his expedition; and besides other recommendations to men of science, he carried a letter of introduction from Boerhaave to Sir Hans Sloane, who was in England as important a character, as a physician and a naturalist, as Boerhave was in Holland. The letter contained this high eulogium of Linnæus : "The bearer of this letter is alone worthy of seeing you ;-alone worthy of being seen by you. He who shall see you both together, will see two men whose 
like will scarcely ever be found in the world."

Linnæus received much attention in England ; and having formed many valuable acquaintance, he returned to Holland, laden with plants and natural treasures for Hartecamp. He was joyfully welcomed back by Cliffort ; with whom he continued the remainder of this year, and great part of the next, busily engaged with his friend's plants, and his own writings.

During this period, he sent no less than six original works to the press. They were, it is true, the fruits of his labour in former years. By means of these publications, his system of botanical reform was spread over Europe. One of these works was a complete list of the plants he had found in Lapland; accompanied with a description of each, according to the new system, as well as of the soil in which they grew, 
and their utility in medicine or in husbandry.

At the solicitation of a scientific friend, he gave to one of the Laponian plants his own name; calling it the Linnaca Borealis. A sprig of this elegant little flower was introduced as a decoration in his coat-of-arms, when, in aftertimes, his talents and industry had been rewarded with riches and honours. In his crest, it surmounted the helmet; the branches hanging gracefully over it. But these times were not yet come.

While at Hartecamp, be published a splendid work, entitled, Hortus Cliffortonianus: being a description of Cliffort's garden, with fine engravings of the rarest plants.

At the expiration of the year 1737 , he could no longer be induced to think of delaying his return to his native country and his betrothed bride, by any 
fresh engagement. Boerhaave, who was still resolved to befriend him, offered him the situation of physician in ordinary to the Dutch colony at Surinam; to which he was empowered to appoint any one whom he thought fit to succeed the late holder of it.

Linnæus had so many inducements to remain in Europe, that he declined the offer without hesitation ; but asked and obtained it for his friend, professor Bartsch, who was desirous of such an appointment. This young man, of whom he had formed the highest expectations, did not long enjoy the advantages his friend had procured him. The climate undermined his health, and he survived his arrival in Surinam only six months. Linnæus was greatly afflicted by his death ; and transmitted his name to posterity, by giving to a plant the appellation of Bartsia. 
He now with regret took leave of Cliffort, and went to pay his parting visits at Amsterdam and Leyden. At this last place he was tempted to prolong his stay awhile, notwithstanding his previous anxiety to proceed homeward. In compliance with the request and even entreaties of professor Van Rozen, he agreed to give him his assistance in arranging the botanical garden there ; and in preparing for the press a work with reference to it.

After this engagement was ended, he again prepared himself for his journey. But the Dutch, who had learned to appreciate his talents, were still desirous to retain him in their service, and to induce him finally to settle in their country.

It was proposed to him to make a botanical royage, at the expense of the republic, to the Cape of Good Hope ; and to receive, on his return, a profes- 
sorship at one of the Dutch universities. By this time, however, his impatience to return to Sweden had become so harassing as to occasion extreme depression of spirits. This, together with his close application to the affairs he had undertaken for Van Rozen, affected his health ; and before he could set out homeward, he was attacked with a severe fever, which confined him six weeks.

Cliffort visited him during his illness, and kindly reproached him for having ever quitted his roof. "If it was your wish to stay in Holland," said he, "I had the first right to your company ; and I would have paid you your annual stipend as formerly." He pressed him to return to Hartecamp as soon as he was sufficiently recovered ; and to remain there until his health was completely re-established. Linnæus gladly escaped from Leyden, as soon as his 
strength would admit; and once more enjoyed the sweets of spring in this beloved retreat, the scene of so many pleasures.

The restoration of his health once more warned him to quit Hartecamp and its kind and generous owner. $\mathrm{He}$ took leave, at length, of all his kind friends, and of that country where his fine talents had been so well appreciated; and travelled home by way of France : being anxious to see Paris, and to be introduced to the literary men there.

He was extremely well received in that city; and indeed his agreeable manners seemed to have made way for him every where; but the predilection the Parisians naturally felt for their countrymen, Tournefort and Vaillant, who were then the great authorities in botany, made them little disposed to receive the reformed system from the 
hands of a young man and a foreigner. They said, "he is a young enthusiast, who confuses every thing, and whose sole merit consists in having plunged botany into a state of anarchy."

"Don't laugh, good people," said the French naturalist Guettard, who perceived at once the merit of the new system; "don't laugh at Linnæus: the time will come when he will laugh at you all."

Before he left Paris, a most unusual compliment was paid him, by his being admitted as a corresponding member of the Academy of Sciences.

After deriving much pleasure from a month's residence in the French metropolis, he proceeded to Rouen; from whence he sailed to his native land. But here another state of things awaited him.

Abroad he had been treated with the $1^{*}$ 
utmost kindness and consideration ; in Sweden he met with coldness and neglect. It was true he was affectionately welcomed home by hisimmediate friends and relatives : but he had no patrons to forward his views; and he was still too poor to marry. He commenced the practice of medicine at Stockholm, as the only means of obtaining support. But, notwithstanding all the celebrity he had acquired, he met with little success. Several causes probably conspired to produce this unfavourable result. There was a strong prejudice against employing, as a medical attendant, a person who was supposed to have devoted almost all his attention to the study of botany, rather than to the healing art.

Besides this, his great scheme of botanical reform, which was a complete innovation on long-established opinions, raised many opponents; some of whom 
treated him and his opinions with harshness and bitter injustice. Amongst these, the foremost was Siegesbeck, professor of botany at St. Petersburgh, whose criticisms were not merely severe; they were really abusive. The odium thrown on him by such ungenerous opponents, operated greatly to his disadvantage. He detailed his difficulties to baron Haller, who loved and valued him, and wrote to him in reply, in a style of condolence highly flattering. "Be happy in your destinies," he said; "you, of whom Flora conceives greater hopes than of all other botanists. Return once more to gentler climes." He then offered to relinquish the professorship of botany at Gottingen to him, and the direction of the botanic garden there, if he would come into Germany.

At the moment this offer reached Linnæus, his prospects were evidently 
brightening at Stockholm; and he therefore declined it with grateful thanks, since he now had hopes of succeeding in his native land. An apparently trifling circumstance led to this improvement in his fortunes.

$\mathrm{He}$ had succeeded in relieving a friend, who applied to him on account of a complaint in the chest. This friend, grateful for his cure, recommended the physician wherever he went. Many suffering from affections of the chest were induced to consult him. At length it began to be considered that no person was so successful in cases of this kind. The lady of an aulic counsellor, who had a troublesome cough, was benefitted by his prescriptions. The medicine was made up in a form which allowed of her carrying it always about her, and using it at any time. One day, while at a card-party at court, her cough was troublesome, 
and she had recourse to her usual remedy. The queen observed her, and asked what she was using. This question called forth praises of the new physician. Her majesty had a cough at the time, and she resolved to take the advice of Linnæus. He prescribed for her, and she speedily lost her cough.

Once more I must bring my epistle to a speedy conclusion. In finishing my last, we left our hero in the luxuriant villa of a Dutch burgomaster; now we leave him in loftier society. My next will inform you how far the atmosphere of a court proved congenial to his fortunes. It is not every man, you know, whose virtues and talents would flourish in such a soil.

Your affectionate Father, 


\section{6}

\section{LETTER VII.}

My dear Henry,

"There is a tide in the affairs of men, which taken at its turn leads on to fortune."

Linnæus now experienced this very thing. Being, as you observe, "fortunately coughed into notice," he soon found himself in the high road to preferment; and Moræus now consented to give him the hand of his daughter. They were married on the 26 th of June, 1739.

Writing to baron Haller, he gives him the following lively sketch of his varying and improving circumstances. 
"I took up my residence at Stockholm. Every body laughed at my botany. No one could tell how many restless nights and toilsome hours I had bestowed on it; but every corner resounded with the humiliating lesson I had received from this Siegesbeck. I began to set up for a practitioner; but my success was very slow. They would not even employ me in a servant's cure. But in a short time adversity ceased to persecute; and, after many clouded days, the lucid sun broke through my obscurity. I rose-was called to the great : every thing turned out prosperous. No patient could be cured without me: from four in the morning till late at night $I$ visited the sick, spent nights with them, and earned money. 'Alas!' said I, 'Æssculapius affords all that is good; but Flora yields only Siegesbecks.' 
"I renounced botany, and resolved a thousand times to destroy all my collections. Soon after, I was appointed first physician to the fleet ; and, after a short lapse of time, the states chose me botanist to the king, and assigned me an annual salary to teach that science at Stockholm. I now grew fond again of plants ; and married my bride, who, after five long years, still thought me worthy of her love."

The patron to whom he owed many of the advantages above alluded to, was count Tessin; who united to high rank great influence as a statesman, and an ardent love of science. He was one of the first to notice Linnæus, on his introduction to court; and he continued to be his powerful and generous friend till his death.

Thus, after encountering many hardships and difficulties, Linnæus at length found the reward of his industry and 
perseverance. I say industry; for what would his genius have done for him, without that indefatigable diligence, with which he pursued his researches in the midst of every obstacle? Men of talent are too apt to suppose that the gifts of nature will effect every thing for them ; and that it is beneath their dignity, and the mark of an inferior spirit, to submit to mental drudgery or bodily labour. Linnæus never drew. back from either; and in the end, you see, he literally verified the truth of Solomon's proverb: "Seest thou a man diligent in his business? He shall stand before kings; he shall not stand before mean men."

Linnæus continued to reside at Stockholm; except that he made some excursions in pursuit of his favourite objects. Honours and affluence now flowed in on him. Three years after, being chosen physician to the fleet, he 
was appointed professor of botany at Upsal; that very university where he had heretofore met with so much contumely and disgrace.

On receiving this desirable and important appointment, he removed thither with his family; and began to re-model the botanic garden, and to pursue other plans for scientific improvement in the university. Having put the garden in order, he sought for rare plants to enrich it: these were sent to him from every quarter. A vast number of scientific men were at that time travelling over various countries, exploring in every place the secrets of nature: among these were many of the personal friends of Linnæus. From these sources, in the course of a few years, he obtained seeds, plants, and other natural curiosities; not only from the most distant parts of Europe, but likewise from the continent and islands of Asia, from 
Africa, and from North and South America. He publicly expressed the satisfaction these acquisitions afforded him, in his address to the university, on the anniversary of the king's birthday, 1752. "I thank Providence," he said, "who has guided my destinies, that I now live; nay, that I live happier than a king of Persia. You know, fathers and fellow-citizens, that I am wholly occupied with this academical garden; that it is my Rhodus, or rather my Elysium. There I possess all the spoils of the east and the west which I wished for; and which, in my belief, are far more precious than the silken garments of the Babylonians, and the porcelain vases of the Chinese. There I receive and convey instruction. There I admire the wisdom of the Creator, which manifests itself in so many various modes, and demonstrate it to others." $\mathrm{He}$ commemorated his gratitude to 
his friends, and especially to those who had contributed to his collections, by affixing their names to plants; either such as were newly discovered, or such as required a change in their names to accommodate them to the new arrangement.

The Kalmia was named in honour of his friend and pupil, professor Kalm, who explored the forests of North America, and brought from that country, this and many other of the beautiful shrubs which now adorn our gardens.

The Magnolia was so called after a French botanist; the Sherardia after an English one; the Celsia after a Sivede, one of his earliest patrons. We might enumerate a multitude, did our time admit. His lectures at Upsal were resorted to by students from Russia, Norway, Denmark, Great Britain, Holland, Germany, and even from America. The hall in which he deliv- 
ered his lectures, was crowded to overflowing.

It was thus the winter was occupied. In the summer he made botanizing excursions, accompanied by a numerous band of his pupils. Every day, on entering the district they intended to explore, they divided into small parties, each of which took a different direction, in order that they might leave no quarter unobserved. When any of the company found a new flower or insect, he blew a few notes on a horn or hugle. At this signal all the scattered parties hastened to assemble at the spot, and Linnæus then proceeded to examine and demonstrate the subject before them. When this was done they again separated and pursued their researches as before.

In this manner, many of the long days of summer were delightfully passed. The knowledge of the students 
was increased, and their love of nature deepened, by being led to read her ample volume in the midst of her own green recesses, afar from all uncongenial sights and sounds. At the same time, many rare productions, hitherto unnoticed, were brought to light. Thus, the interests of science were promoted in every way; and the pupils became still more attached to their amiable and interesting instructer. Indeed, he was at once their teacher, their companion, and their friend.

Time passed on, and fortune and fame still attended his steps. Distant countries offered him flattering testimonials of esteen, by voluntarily conferring on him memberships in their different universities and scientific societies. He was a member of three in Germany, three in France, three in England, three in Italy, two in Holland, one in Switzerland, one in Denmark, and one in America, besides 
three in his own country. He received from many of his opulent pupils splendid presents of plate, \&c. One of these, who travelled in China, sent him from thence a service of porcelain, decorated with a delicate representation of the Linnaa Borealis, as its only ornament.

Nor were literary men the only persons who were anxions to show their esteem for him; kings and princes paid tribute to his genius. Two kings of Sweden, in succession, Frederic the First and Frederic Adolphus his successor, were his patrons. The latter created him Knight of the Polar Star, and granted him a diploma which raised him to the rank of the hereditary nobility of the country. Previously to this, the king of Spain had caused him to be invited to that country, to become his botanist; offering to give him a handsorne salary, to allow him the free exercise of his religion, and to create 
him a nobleman. Such honours had never been granted to a protestant by the catholic court of Madrid. Linnæus, however, declined the offer : and no doubt received his rank from his own sovereign, some time afterwards, with much more satisfaction than he would have felt had it been conferred by a foreign monarch.

The empress of Russia, who was a liberal patronizer of the sciences, and of scientific men, sent him presents ; as also did the king of Denmark.

Louis the Fifteenth complimented the king of Sweden, when he was at Paris, on possessing such a man as Linnreus in his kingdom ; and gave orders that plants and seeds of the rarest description should be selected from his garden at Trianon to send to him.

The empress of Germany, likewise, and the king of Sardinia, complimented the Swedish ambassador in a similar 
way ; and Frederick the Great spoke of him in the highest terms of praise.

Meanwhile, as his fortune increased, he began to long more ardently than ever for some country retreat, which, though less princely than Cliffort's, might secure to him many of the enjoyments of Hartecamp. He purchased the villa of Hammarby, a league from Upsal ; and for the last fifteen years of his life he made it his summer residence. His pupils, unwilling to lose the advantages of his instruction, followed him thither; and many of those who came from a great distance, took lodgings in the villages of Honby and Edeby, which were both contiguous to his estate. It was his practice to deliver his lectures to his private pupils in a familiar manner, and not with the form and solemnity of a professor. One of these students has left us an account of the way in which their time passed, when himself and two others 
young foreigners were in attendance on Linnæus. His deseription conveys so pleasant an idea of the terms on which he lived with his pupils, that I cannot deny myself the pleasure of giving it you, in the words of the writer.

"For two whole years have I been so fortunate as to enjoy his instruction, his guidance, and his confidential friendship. Not a day elapsed in which I did not see him--in which I did not either attend his lecture, or, as it frequently happened, spend several hours in familiar conversation with him. In the summer we followed him into the country. We were three, all foreigners. In winter we lived directly facing his house ; and he came to us almost every day, in his short red dressinggown, with a green fur-cap on his head, and a pipe in his hand. He came for half an hour; but stopped a whole one, and many times two. His conversation, on these occasions, was extremely 
pleasant and sprightly. It either consisted in anecdotes relative to the learned in his profession, with whom he got acquainted in foreign countries; or in clearing our doubts, or giving us other kinds of instruction.

"Our life was much happier when we resided in the country. Our habitation was about half a quarter of a league distant from his house at Hammarby, in a farm, where we kept our furniture and other requisites for housekeeping. He rose very early in summer ; mostly about four o'clock. At six, he came to us, because his house was then building; breakfasted with us, and gave us lectures on the natural orders of plants, as long as he pleased; generally till about ten o'clock. We then wandered about till twelve upon the adjacent rocks, the productions of which afforded us plenty of entertainment. In the afternoon we repaired to his garden; and in the evening we 
mostly played at the Swedish game of trisset, in company with his spouse."

Nor was it only students he attracted to his retreat. It was in fact a little court. No stranger of importance, however high his rank, ever came to Upsal without visiting the naturalist at Hammarby. His family, consisting of one son and four daughters, grew up around him; and as he advanced in years he had the satisfaction of seeing his son appointed his assistant in the botanical professorship, with a promise that he should succeed his father in the office.

And now, Henry, let the call your attention to one circumstance particularly worthy of notice.

In the midst of his prosperity, Linnreus did not forget that he owed all to a merciful God. He said not in the boastful spirit of unhallowed self-sufficiency, "By my own might and my own wisdom have I gotten me the victory ;" but was ever ready, in public 
and in private, to acknowledge the gracious hand that led him safely through so many perils, and showered unhopedfor blessings on his path. He could never look back on the scenes through which he had passed, without being affected by the consideration of the mercy and goodness which had attended him.

He drew up a little memoir of the most striking circumstances in his life, and concluded it with these words: "The Lord was with thee wherever thou didst go." lt is said, that whenever an opportunity of expatiating on the wisdom and goodness of the Almighty occurred in his lecture, he seized it with avidity. On such occasions, he spoke with even greater animation than usual, and the finest bursts of eloquence broke from his lips.

Such was Linnæus: highly gifted by hature, amiable in his dispositions, and exemplary in his conduct in no common degree. You will say with 
Ellen, "Alas! that any shade should be cast over so fair a picture!" But since we kuow that He whose word is truth, has declared that the heart of man is deceitful above all things, and desperately wicked; and that there is none wholly righteous, no, not one, we ought not to expect that any human being should pass in review before us, without our discovering some of his errors; while many of them will remain known only to Him who seeth all things. The besetting sin of Linnreus is said to have been the love of money. He was, however, kind, and even liberal, to many of his pupils.

His health and spirits were continued to him till his sixty-eighth year; when his intellectual and bodily vigour both began to give way. A gradual decay broke down his constitution; and he died in his seventy-first year. Sweden mourns his loss : it was felt by the university of Upsal in particular. 
His lifeless remains were conveyed to the cathedral, with every mark of respect ; all the professors, officers, and students of the university following in procession. In the opening of the diet, or senate of the kingdom, in that year, the king of Sweden commanded his chancellor to read a sketch he had drawn up, of his government and enterprises, during the six preceding years. In this paper he made the most honourable mention of Linnæus ; lamenting his loss as irreparable, and thus making his public eulogium. Medals were struck in honour of him ; busts were cast, and many other honours paid to his memory.

His manuscripts and his collections, which were sold by his widow some years after his death, are now in the hands of an Englishman, Sir James Smith. They had been offered to Sir Joseph Banks, who recommended Sir J.Smith to become the purchaser. But scarcely had he agreed to the terms 
proposed, when munificent offers were made from Russia. At the same time the king of Sweden, who had been absent from his kingdom, returned ; and finding what had been done in his absence, sent a vessel in chase of the ship which was eonveying them to England, with orders to bring back these scientific treasures. The British vessel had made such good progress that she could not be overtaken, and the cargo arrived in safety at its place of destination.

The son of Linnæus, though he did not possess his father's great talents, inherited his love of natural history, and was treading in his steps with great ardour, when a severe fever gave an irrecoverable shock to his health; and five years after, he sunk into the grave, in the forty-second year of his age. $\mathrm{He}$ was buried in the cathedral of $\mathrm{Up}_{\mathrm{p}}$ sal, by the side of his father. By his death, the male branch of the ennobled 
family of Linnæus became extinct ; and according to the custom of the country, his coat-of-arms was consequently broken to pieces. The gardener of the university then strewed flowers over the tombs of the two Linnæuses.

Thus, the "boast of heraldry" proved truly a fleeting honour in the family of Linnæus. But his fame rested not on so frail a basis. Few persons, comparatively, are aware that he ever attained to the rank of nobility; but in every civilized country, multitudes are familiar with his name, as a naturalist and man of science. In fact, his memorial is found wherever the green earth spreads abroad her treasures.

I rejoice to hear you pursue your botanical researches with so much energy ; as, besides the advantages hereafter to be derived from the study, the pleasure it will afford you, even in the present moment, will more than com- 
pensate for any exertion you may have to make.

\section{Ellen, who is sitting by me, has just} said, "Papa, there are Handel commemorations; and many other great men have had honours paid to their memory in the same way : why should not we have a Linnæus's commemoration ?"

"Well, my dear Ellen," I replied, "we will have one, since you wish it." Time and place, however, we have not fixed on. What say you, Henry, to the $3 \mathrm{~d}$ of May, as the anniversary of the birth-day of Linneus? But I shall leave you to talk over the affair with your sister, when you meet; which I trust you will do next week.

We are all impatient to see you; and no one more so, than

Your affectionate father, 



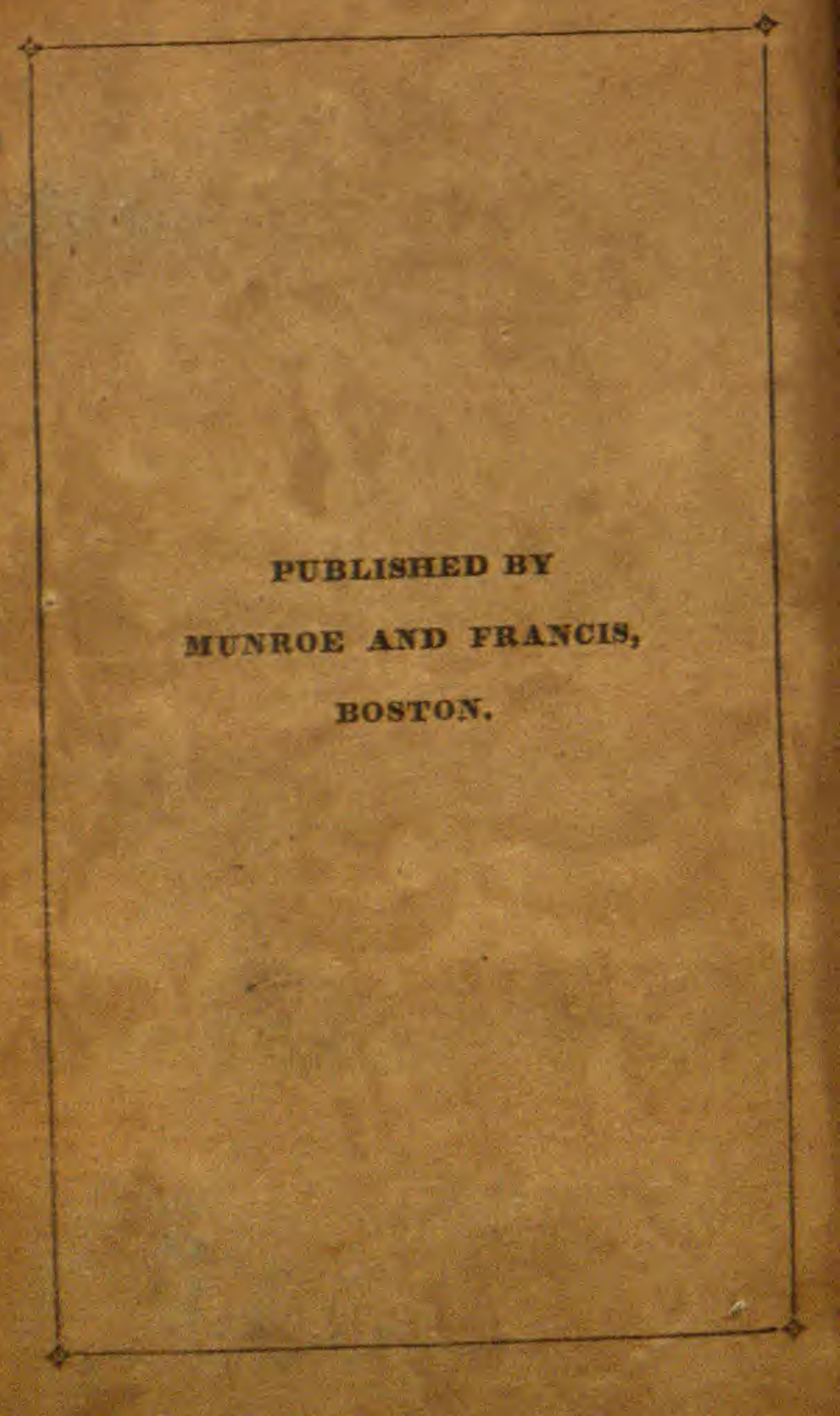

